\title{
New Way of Identification of a Place and Tracking
}

\author{
T. Harinarayana, Pitambar Sai Goyal*, N. Rajendran \\ B.S. Abdur Rahman Crescent Institute of Science and Technology, Chennai, India \\ Email: director.cers@crescent.education, t.harinarayana@gmail.com, ^lasawfwiah@gmail.com
}

How to cite this paper: Harinarayana, T. Goyal, P.S. and Rajendran, N. (2020) New Way of Identification of a Place and Tracking. International Journal of Geosciences, 11, 360-376. https://doi.org/10.4236/ijg.2020.116019

Received: April 8, 2020

Accepted: June 6, 2020

Published: June 9, 2020

Copyright $\odot 2020$ by author(s) and Scientific Research Publishing Inc. This work is licensed under the Creative Commons Attribution International License (CC BY 4.0).

http://creativecommons.org/licenses/by/4.0/ (c) (i) Open Access

\begin{abstract}
Identification of a place and navigation to reach are two most important things for any traveler. Although Google map has been helping the society at large in many ways, it has some disadvantages. For example, all the postal addresses cannot be identifiable through Google map APP. There is no unique place for identification as popular name of a location has several places. Additionally, it depends wholly on GPS accuracy and may sometimes be away from the desired location by 100 meters. Some of these disadvantages are overcome from our new way of identification of a place. Our innovation is simple but its applications are many. We can provide code for any place on the land, water or ice-covered surface of this planet with 8-digit alphanumeric code (TH code). This code is integrated with Google map and implemented in Android based mobile phones and can easily be extended to IOS based Apple mobile phones as well. The accuracy of our code location is about one meter anywhere in the world. To get the code of a location, GPS is not required but internet service is necessary. However, to navigate from one place to the other both GPS and Internet are required. Our APP is quite simple to operate and useful to many and has applications at least in ten different sectors. In this present-day Corona virus scenario, our APP is vital to track human beings, goods, medical equipment etc. to reduce human loss, economy loss due to quarantine/lockdown issues and it is the need of the hour.
\end{abstract}

\section{Keywords}

Mobile App, IoT, Navigation, TH Code, Coronavirus

\section{Introduction}

Introduction of internet and mobile phone services have taken major revolution in communication between human beings and also on data analysis. It has made 
the life of all the humanity easier than before. Among various advantages, use of digital maps through computers and mobile phones has become essential for all those national and international travelers. This facility has crossed the developed countries and presently being used by many developing and even underdeveloped countries. Recent advances in mobile communication, accurate location and positioning through sensor technology networks are the driving forces pushing mobile-networked systems with new services and applications [1].

Digital maps are quite helpful to use in mobile applications [2]. Among various digital maps, Google map is more popular. Although, Google map APP has provided many options intelligently, it is suffering from a few disadvantages. For example, some of the addresses in a city or town cannot be recognizable. Similarly, Google map may display many locations for a popular name of the place. For example, "Gandhi Road", "Nehru Street" are popular names in India and there may be more than one place with the same name in a city or town. This way, the user has no idea which location he needs to go. Additionally, GPS has some limitations on accuracy and the user may find it difficult to identify the exact location.

Some of the disadvantages of the Google map have been identified and solved innovatively in our APP. Our APP has many advantages and a larger number of sectors can be the beneficiary. This will be explained in the following more clearly considering one application after the other in Section 3 below. Using our application, one can get a simple 8-digit alphanumeric code, herein after called "TH code" for any location in the world. The accuracy of the location is about 1 meter.

Our APP can easily be modified to include smart monitoring facility to save the lives of many human beings. In the present crisis of Coronavirus, monitoring of human spatial mobility is very important. People affected with positive test result need to be monitored, especially on their movement accurately. Additionally, those persons who are arriving to their own home country after travelling from the virus affected country also need to be monitored with clear instructions. Their movement need to be restricted as the virus starts affecting the persons with symptoms such as cough, cold, fever etc. after about 3 to 6 days of time of their arrival. For this reason and also for various other reasons, monitoring of the persons movement forms very important for any country [1] [3]. Our App, if installed with a slight modification in smart watches of the persons, one can monitor and trace the persons easily. This saves millions of dollars to quarantine the places and saves many healthy persons. All the above with practical examples are described in the following sections.

\section{About Our Innovation}

In early days, Latitude and Longitude are only the two parameters to locate the place anywhere in the world (Figure 1). Later developments have taken place and Northings and Eastings came. However, these two parameters contain 16 or 


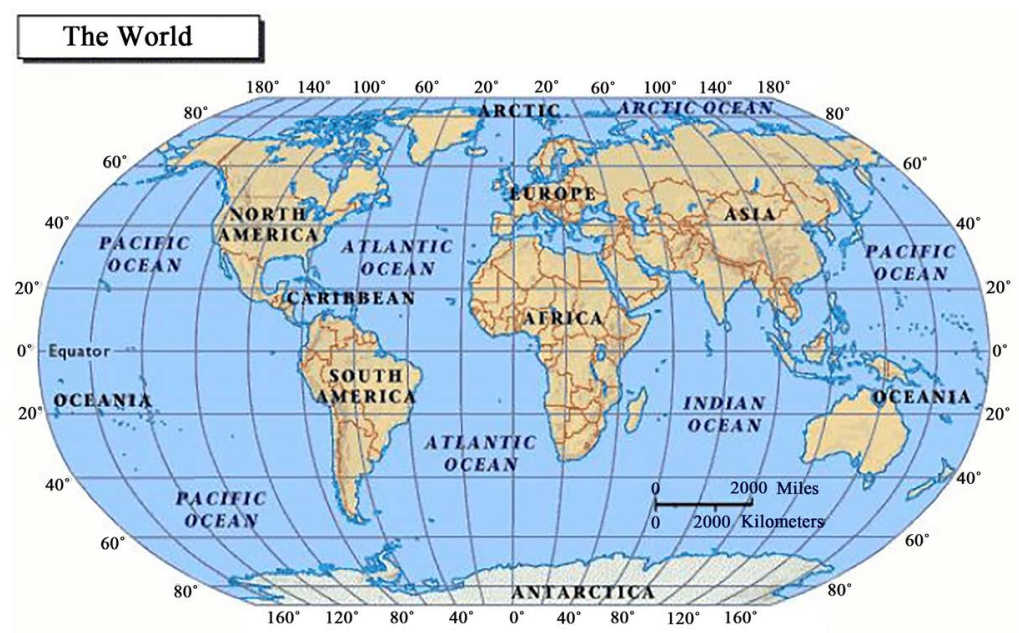

(a)

UTM Zone Numbers

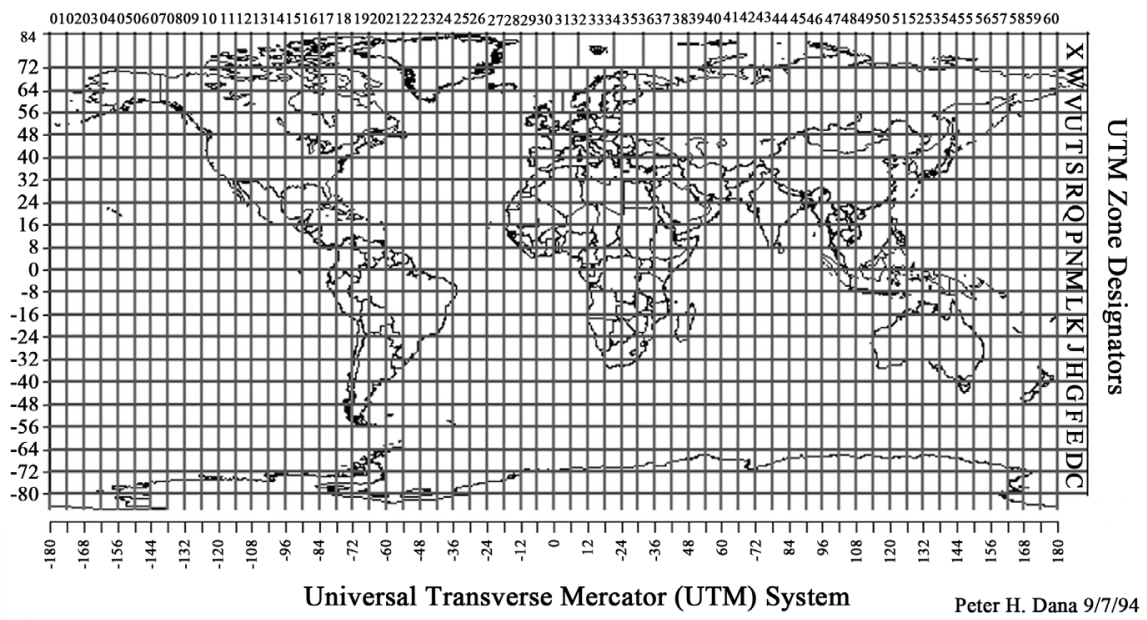

(b)

Figure 1. (a) World map in the form of a globe showing the Latitude and Longitude lines. Latitude varies from 0 - 90 towards north from the equator and 0 to -90 towards south of the equator; (b) World map projected on a plane showing Eastings and Northings as per Universal Transverse Mercator (UTM) system. Values of Northings and Eastings follows UTM zones demarcated grid wise.

more digits for about 1-meter accuracy and difficult to remember. Accordingly, all the persons are used to declare the location through name etc. with land mark details. Latitude and Longitude or Northings and Eastings are being used by a very limited scientific community. Common man has no idea about these parameters. Postal or Courier system are primarily being followed the old system of writing the name of the person, name of the street, name of the village or a place, name of the district, name of the state, name of the Nation etc. details along with relatively new idea of PIN code or Zip code system. All these are long, cumbersome and complicated and will now become obsolete soon with more and more persons start using our code.

Our innovation is based on conversion of northing and easting and Lat \& 
Long numbers into a simple alphanumeric code. Our innovation in the form of a patent filed at Chennai (No.201941041489 and 202041019146). It has application in various commercial establishments, industries, especially the various postal \& courier agencies. Our App is integrated with Google map. It is developed, installed and tested on Android smart phone system (see http://www.getme-thcode.com/ for details) and it is now available to all through Google play store. The tested results of our APP are presented as screen shots with details in Figure 2 and our code with Lat-Long numbers are provided in Tables 1-5.

\section{Applications}

\subsection{House Address vs. Google Map}

The present practice of locating the house or a place is through conventional address system. Recently digital maps are helping to locate the houses in the city

Table 1. List of the locations in BSAR Crescent Institute of Science and Technology, Vandalur, Chennai.

\begin{tabular}{|c|c|c|c|}
\hline S. No & Name of the Location & Universal Code & Lat-Long \\
\hline 1 & $\begin{array}{l}\text { Main Gate of Crescent Institute of Science } \\
\text { and Technology, Vandaluru, Chennai }\end{array}$ & AVy'T’Tofr' & $\begin{array}{l}12.877490 \\
80.084690\end{array}$ \\
\hline 2 & Auditorium main gate of the above institute & AVx'v'Tofr' & $\begin{array}{l}12.876739 \\
80.084677\end{array}$ \\
\hline 3 & Entrance to New Staff Quarters of the same institute & AVw'rTohC & $\begin{array}{l}12.875931 \\
80.086107\end{array}$ \\
\hline 4 & VC Office of the same institute as above. & AVx'HTOfH & $\begin{array}{l}12.876172 \\
80.084163\end{array}$ \\
\hline 5 & $\begin{array}{l}\text { Chennai Domestic Airport arrival } \\
\text { gate 2-Madras Coffee house, Chennai, Tamil Nadu }\end{array}$ & Awe9Tlm'r' & $\begin{array}{c}12.9830918 \\
80.166696\end{array}$ \\
\hline 6 & $\begin{array}{l}\text { MGR Central Railway station-Chennai } \\
\text { central drop point, Chennai, Tamil Nadu }\end{array}$ & AXda'T2x'3 & $\begin{array}{l}13.082558 \\
80.276027\end{array}$ \\
\hline
\end{tabular}

Table 2. List of different places in major cities of India-Bengaluru, Hyderabad, Delhi, Mumbai and Kolkatta.

\begin{tabular}{|c|c|c|c|}
\hline S. No. & Name of the Location & Universal Code & Lat-Long \\
\hline 1 & Bengaluru airport, Uber Parking area & AYx8Sy'BF & $\begin{array}{l}13.1990802 \\
77.7111482\end{array}$ \\
\hline 2 & $\begin{array}{l}\text { Rajiv Gandhi International airport, Shamshabad, } \\
\text { Hyderabad, Plaza premium lounge, Departure terminal }\end{array}$ & At'D't'SfVX' & $\begin{array}{l}17.2367165 \\
78.4285456\end{array}$ \\
\hline 3 & $\begin{array}{l}\text { Mc Donalds fast food, Indira Gandhi } \\
\text { international airport, Arrival Terminal-3, Delhi }\end{array}$ & BgX'g'Sr'fM & $\begin{array}{l}28.5536232 \\
77.0841959\end{array}$ \\
\hline 4 & $\begin{array}{l}\text { Pizza Hut, Chatrapati Shivaji } \\
\text { international airport, Mumbai }\end{array}$ & Anmn'SVh'S' & $\begin{array}{l}19.0896784 \\
72.8634789\end{array}$ \\
\hline 5 & $\begin{array}{l}\text { Travel Club Lounge, Netaji Subhas Chandra } \\
\text { Bose international airport terminal, Kolkata }\end{array}$ & BTN'DTfG'x' & $\begin{array}{l}22.6441264 \\
88.4397519\end{array}$ \\
\hline
\end{tabular}




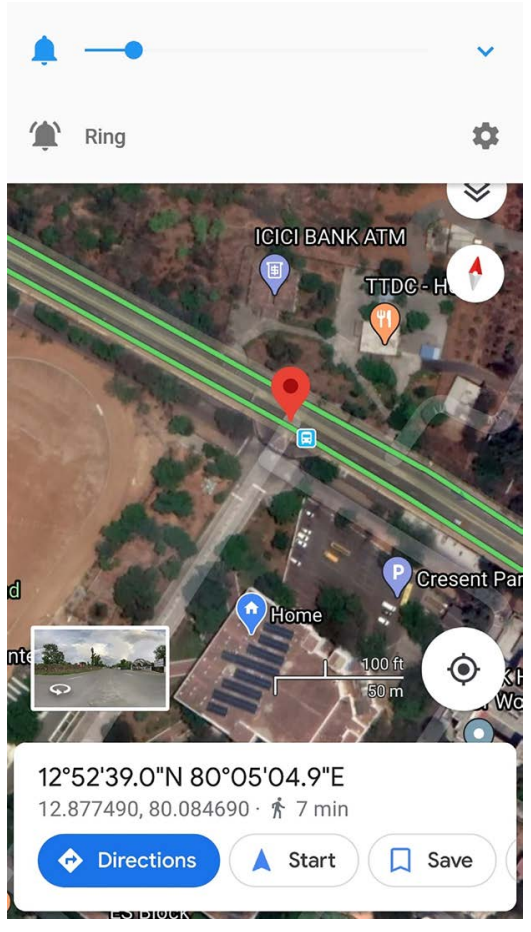

(a)

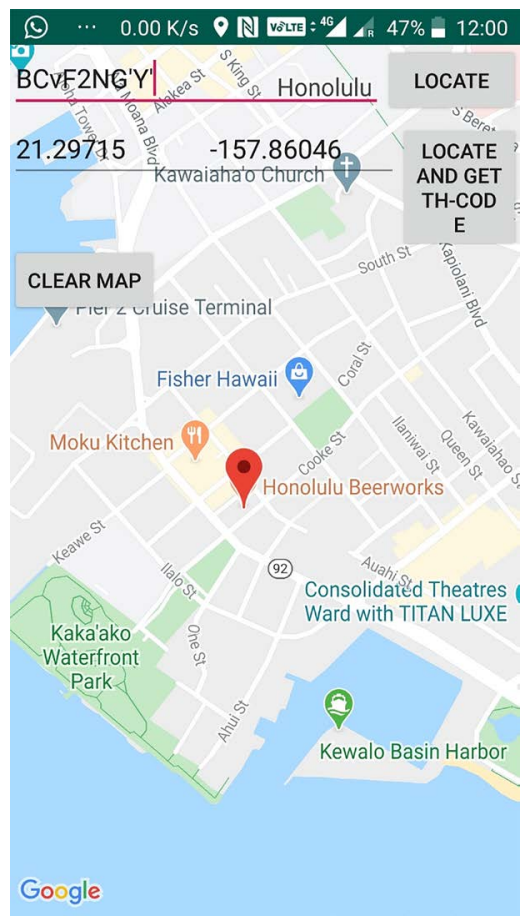

(c)

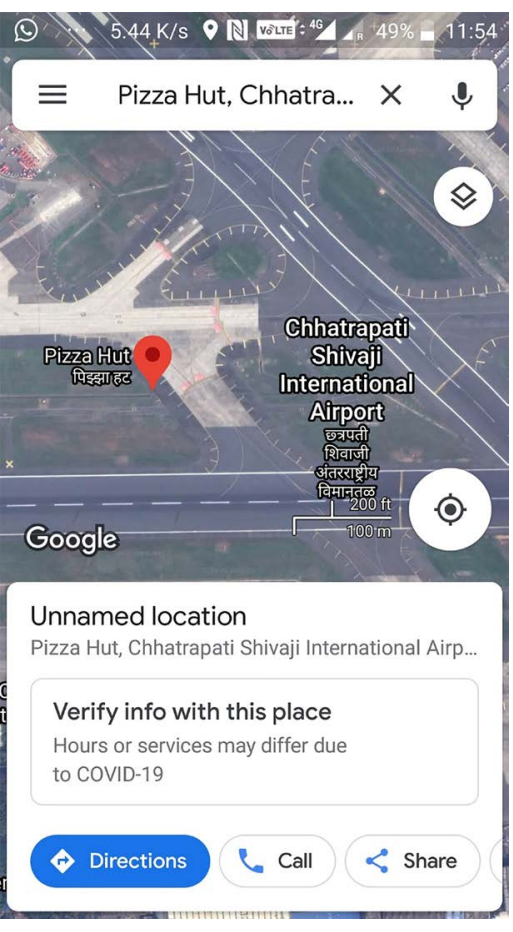

(b)

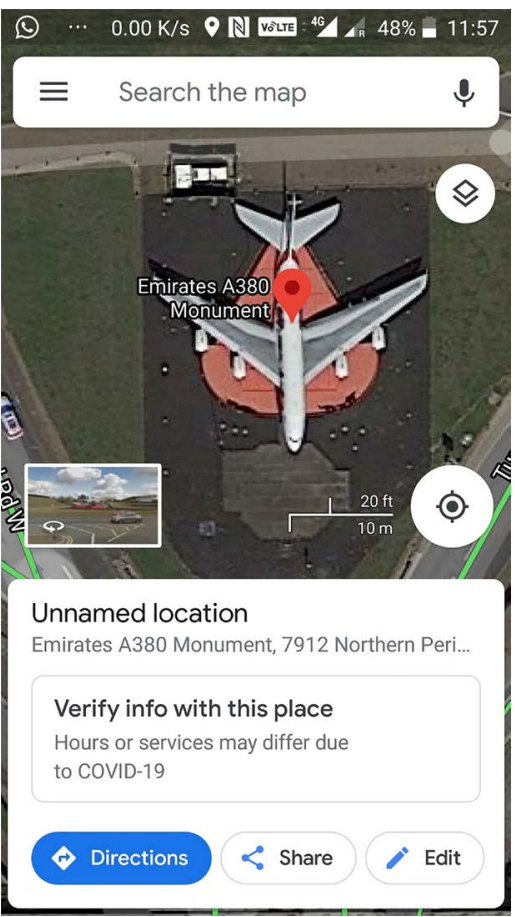

(d)

Figure 2. Few examples of screen shots of different locations showed in the tables above. (a) Main gate of the BSAR Crescent Institute of Science and Technology, Vandaluru, Chennai-Refer Table 1 S. No. 1; (b) Pizza hut, Mumbai international airport, Refer Table 2 S. No.4; (c) Honolulu Beer works, Honolulu Island, Pacific Ocean, refer Table 4 S. No.2; and (d) A380 monument, Heathrow Airport, London, refer Table 3 S. No.2. These locations can be reached by providing Lat-Long values using Google APP or TH codes using our APP. 
Table 3. Details of different locations around the world, US, UK, Japan, Germany and Russia with our TH code.

\begin{tabular}{|c|c|c|c|}
\hline S. No. & Name of the Location & Universal Code & Lat-Long \\
\hline 1 & $\begin{array}{l}\text { JFK club house, A5 Gate, JF Kennedy International } \\
\text { airport, Terminal-4, NewYork, USA }\end{array}$ & D6M'K'Ag'MV' & $\begin{array}{c}40.643416 \\
-73.779486\end{array}$ \\
\hline 2 & $\begin{array}{l}\text { A380 Emirates Monument point, Heathrow Airport, } \\
\text { London }\end{array}$ & EEbs'HtR'4 & $\begin{array}{r}51.480704 \\
-0.452962\end{array}$ \\
\hline 3 & $\begin{array}{l}\text { Blue seal Restaraunt, Haneda Domestic Terminal 2, } \\
\text { Between North and South Exit,Tokyo, Japan }\end{array}$ & CZ'V’4YvkM & $\begin{array}{c}35.551040 \\
139.788204\end{array}$ \\
\hline 4 & $\begin{array}{c}\text { Mc Donald's Frankfurt airport, Terminal-1, } \\
\text { Frankfurt, Germany }\end{array}$ & E0YU'Jgeq & $\begin{array}{c}50.031489 \\
8.583929\end{array}$ \\
\hline 5 & $\begin{array}{l}\text { Coffee Box point, Sheremet'evo 1, Sheremetyevo-AS } \\
\text { Pushkin international airport, Moscow, Russia }\end{array}$ & Ed'cz'Nv'Em & $\begin{array}{l}55.981774 \\
37.414886\end{array}$ \\
\hline
\end{tabular}

Table 4. Remote island locations in different seas, namely, Papua New Guinea, Honolulu Island, South Georgia Island, Indian Ocean and Greenland sea.

\begin{tabular}{|c|c|c|c|}
\hline S. No. & Name of the Location & Universal Code & Lat-Long \\
\hline 1 & $\begin{array}{l}\text { Crows Nest Hotel, Daru Airport, Daru Island, } \\
\text { Papua New Guinea }\end{array}$ & 89BvZZ4P & $\begin{array}{l}-9.088027 \\
143.204217\end{array}$ \\
\hline 2 & $\begin{array}{l}\text { Honolulu Beerworks restaurant, Cooke Street, } \\
\text { KAKA'AKO area, Honolulu Island, North Pacific Ocean }\end{array}$ & BCvF2NG'Y' & $\begin{array}{c}21.297145 \\
-157.860455\end{array}$ \\
\hline 3 & Mt, Paget, South Georgia Island, South Atlantic Ocean & 3Z'e’DEB’N'd & $\begin{array}{l}-54.439863 \\
-36.555182\end{array}$ \\
\hline 4 & $\begin{array}{l}\text { Eglise Nore-Dame des Vents, Port-aux-Francais, } \\
\text { Morbhihan Bay, Indian Ocean }\end{array}$ & 46R'fS2F0 & $\begin{array}{c}-49.352159 \\
70.214988\end{array}$ \\
\hline 5 & $\begin{array}{l}\text { Hotel Tulpan, Pyramiden, SVALBARD Island, } \\
\text { Greenland Sea, North Atlantic Ocean }\end{array}$ & GhZ'NKh'Vc' & $\begin{array}{l}78.655218 \\
16.328590\end{array}$ \\
\hline
\end{tabular}

Table 5. Postal addresses in different cities-Hyderabad, Bengaluru, Chennai and New Delhi.

\begin{tabular}{|c|c|c|c|}
\hline S. No. & Address Details & $\begin{array}{l}\text { Our universal } \\
\text { Code }\end{array}$ & Lat-Long \\
\hline 1 & $\begin{array}{c}\text { Mr.xxxx, 1-49/6F, Maruthi Nilayam, Street No. 3, } \\
\text { Suryanagar Colony, Opp. Brahmakumari Samajam, } \\
\text { Uppal, Hyderabad, } 500039\end{array}$ & Au'veSgg'D & $\begin{array}{l}17.39783 \\
78.56214\end{array}$ \\
\hline 2 & $\begin{array}{l}\text { Ms.yyyyy, A-Block, Flat } 105 \text { Brigade Metropolis, } \\
\text { Mahadevpura, Bengaluru, Pin: } 560048\end{array}$ & AWpc'Sy'1z' & $\begin{array}{l}12.99158 \\
77.70178\end{array}$ \\
\hline 3 & $\begin{array}{l}\text { Mr.zzzzz, Dy. Mayor Kabalamurthy Road, Adj. to } \\
\text { Chintadripet Higher Sec. School, Chintadripet, Chennai }\end{array}$ & AXw'g'T2u'M & $\begin{array}{l}13.075619 \\
80.273176\end{array}$ \\
\hline 4 & $\begin{array}{l}\text { Mr.XXX CSIR Scientists Apartments, Maharani bagh, } \\
\text { Ashram Chowk, New Delhi }\end{array}$ & Bgt'KSt'd'M & $\begin{array}{l}28.5721876 ; \\
77.2591877\end{array}$ \\
\hline
\end{tabular}

or towns etc. using this address system and help the user to navigate to that location [4]. However, the present system is facing some difficulties. As an example, we show the limitation of the Google map in identification of the houses through 
postal address. For example, all the postal addresses could not be recognized by the Google map. If one tries to feed his postal address, in Google map APP, it can show many locations as the probability. One sample address at Hyderabad city is provided to search by the Google map APP. It has shown three places as the probability (see Figure 3 ). In fact, each location is away from each other by a few kilometers. In fact, Google map has interpreted each line of the address as a different place altogether. For a new user, it is difficult to identify the correct location among the three given options to match the postal address. We suggest to use our simple code system, instead of address. Any user can have TH code through our APP from our website (which can be downloaded for individual use from http://www.getme-thcode.com/), can locate the place accurately.

We suggest all houses can have our universal code as their address. It greatly helps the present address system. This helps a lot to all Municipality officers, Town planning officers, survey officers to avoid providing the complicated house number system presently being followed. People can display our 8-digit universal TH code on a board and can hang it on the doors/houses. This can be followed by all at every place around the world uniformly. This new system, if implemented may probably revolutionize the house address system and our present address system will become obsolete.

\subsection{Promotion of Mobile Service Providers}

In the present-day stiff competition of mobile communication, there are many mobile phone models are being released with new features and the data can be analyzed to understand its effective use [5]. Similarly, there is a stiff competition

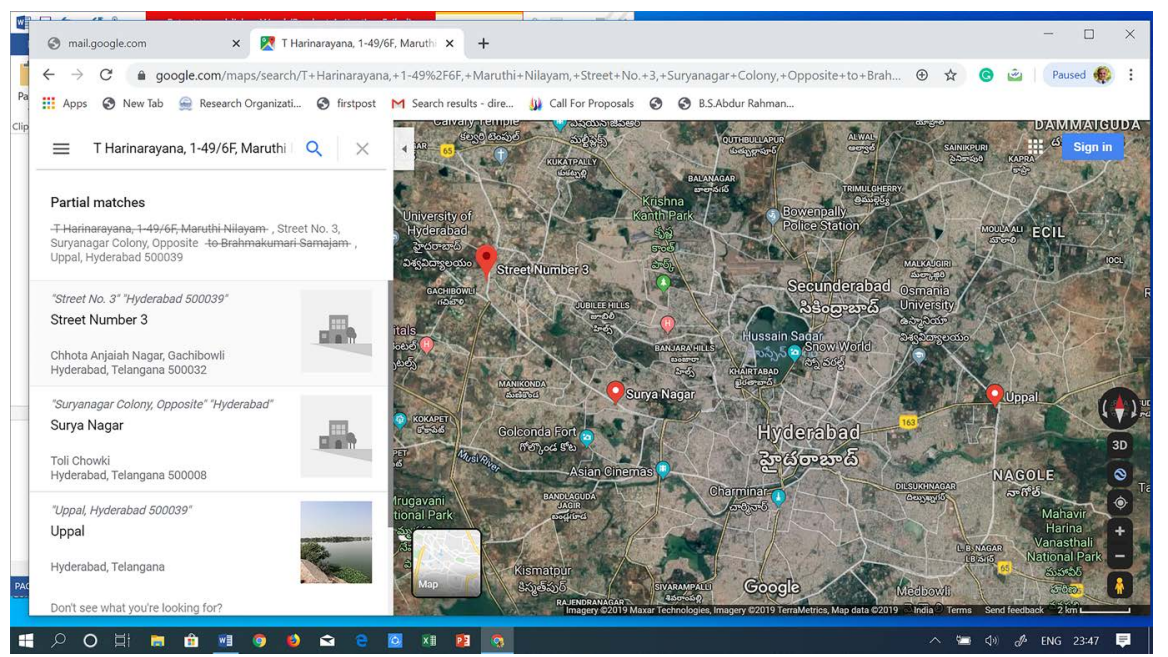

Figure 3. Here Google map has been searched with the postal address as Street number 3, Suryanagar Colony, Uppal, Hyderabad 500039. This has resulted in showing 3 possible locations as the probable places interpreting each line as one separate location. This way user faces the problem of finding unique location of his desired place. Instead of the address, providing the 8-digit TH code as Au've Sgg'D the map shows only one unique preferred desired place. This way our newly developed APP has an added advantage over the present option available in the APP. 
among service providers also. In India, BSNL, Airtel, Vodafone etc. are more popular. Each country has their own service providers with new features. They compete each other promoting their additional features which don't exist in other service provider or their service is superior in coverage, speed etc. facilities to promote their customers. Let us consider these service providers are A, B or C.

In such a scenario, our APP feature can be incorporated by one service provider (e.g. A) as their extra service to the users and thus can attract more customers. For example, while taking the service the user needs to provide a unique postal address. The service provider "A", while allocating the mobile number can also allocate the unique $\mathrm{TH}$ code belonging to his address. This greatly helps all the users of this Service "A" provider for easy communication of their address with others with code. Optionally, while sharing his mobile number with others, he can also share his unique TH code (Figure 4). The service provider, using our APP can match the address and get the code with a simple touch of his house or apartment complex. This way, the user $\mathrm{X}$ not only sharing his number but also his house address as per his option. Optionally, he can avoid sharing his address (TH code) due to privacy reasons and he can only share with a selected few. The other user $\mathrm{Y}$, who has full information about the user X (both mobile number and $\mathrm{TH}$ code) need not remember his complete address any time to reach his place. The 8-digit TH code will provide and guide him to navigate to his house or business establishment. Such facility can be provided not only to the new customers but also to the old customers. The old customers can get this code by locating their address through our APP and with a touch of a button can get the code and the same can be stored into their contact details along with Email and other details. This way, both the old and new customers are benefitted through the service provider. Since our APP is based on patented technology, our APP can be used more effectively to any service provider.

\subsection{Courier and Postal Service}

Postal services all over the world is helping the society in many ways for more than 100 years [6]. There are large movement of goods, postal letters, parcels, gifts from a firm or from a person that need to be carried from location " $\mathrm{A}$ " to

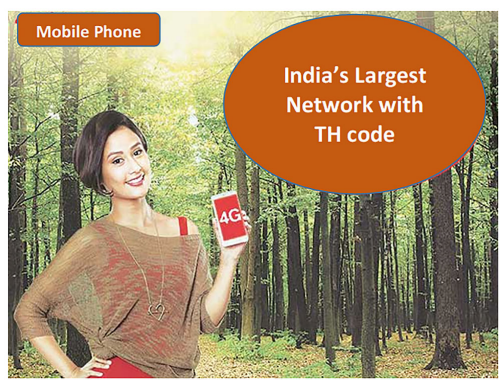

Figure 4. Mobile phone service providers can advertise that they not only provide the good service, they will also support TH code which can make the navigation much easier and helpful to the community and friends. 
"B" (Figure 5). All require lengthy address details, usually contains 5 to 6 lines along with the name of the person to be delivered. Some may need to provide a landmark as well for the courier man for easy identification. All such procedures are lengthy and involve lot of time. In fact, our code does not require any known address. Without address also one can have this code. This way, new places also finds our code handy and very useful to work with postal and courier system persons to get the goods delivered without ambiguity.

In our TH code, just two lines are enough to send goods or letters etc. to anywhere in the world. First line is the name of the person and the second line is TH code. In case he is staying in a multilevel complex building, his flat or apartment number also required along with his name. This way lot of paper can be saved, additionally sorting of the items at a central location will be easier. Less writing on the labels, less memory in the computer storage is additional benefits. In recent years, drone delivery system is coming. Drone need to be guided with accurate location. Just address is not enough. Using our code, one-meter accuracy is possible. This way the user can decide whether he needs the item to be delivered in the front yard or back yard of his address as per his choice using our TH code. Drone will navigate its path based on the given code and deliver the goods.

\subsection{Emergency Services}

Waiting time in emergency in hospitals is a major issue in some countries [7]. In many occasions, for example, fire accident and medical emergency, one need to reach the place urgently without ambiguity (Figure 6). Majority of the time, the emergency vehicle arrives close to the place but not at the actual place due to poor address details. This way the crucial time is lost due to bad communication and address details. For example, fire engines and ambulance services are presently facing this issue at many places. Our present address system is not user friendly, especially in many developing and under developed countries it is difficult to reach the place. In such situations, our TH code will be of great help. The affected person need not have a smart phone, even through normal phone, he can communicate the code to the service man. Once the emergency services are informed about the TH code of the location, using our APP, he/she can easily reach the location without ambiguity.

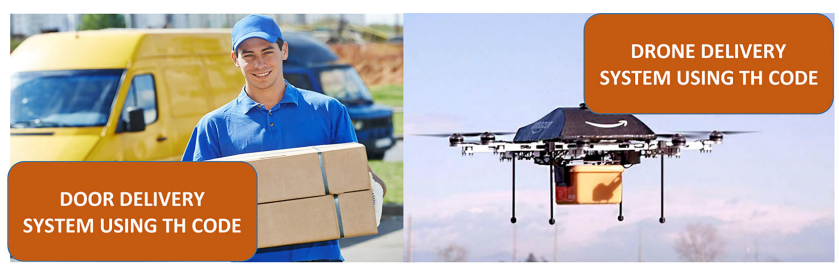

Figure 5. (a) Courier boy or post man delivering the goods-door delivery without ambiguity and (b) Drone delivery system using our TH code. This greatly helps the drones to navigate to the destination more easily, for example delivery can be in the front side of the house or backside of the house etc. 

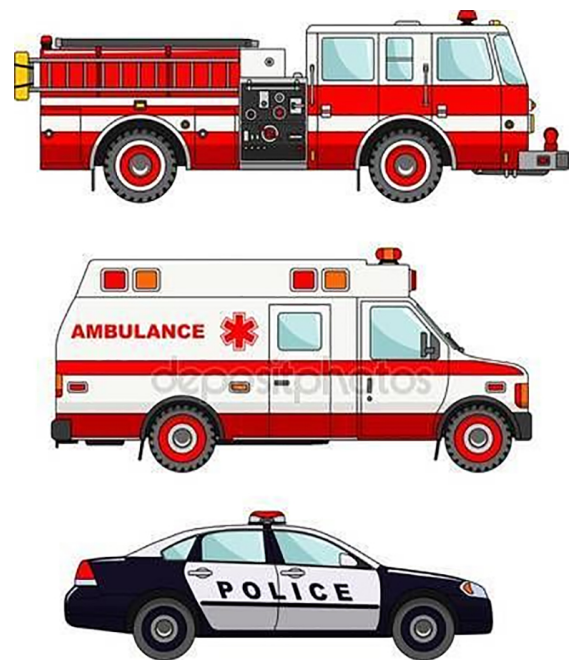

Figure 6. Our TH code is very much helpful in emergency services such as Fire accidents, medical emergency or Police urgency etc. to reach the location with high accuracy and with ease.

\subsection{Taxi Services}

In the recent past, through innovative app technology UBER taxi service (with international brand) and other local taxi services are helping the society to a great extent for easy and comfortable transportation of the people with affordable price etc. [8]. In India, apart from UBER there is OLA, FAST TRACK etc. services also exist (Figure 7). Similarly, many countries have their own local taxi services. They all made our life easier with innovative concepts. However, often the drivers get confused with loss of GPS navigation or inaccurate GPS navigation system etc. and end up in a wrong location or away from the actual location by about $100 \mathrm{~m}$ or end up in a neighboring lane or road and this is quite annoying to the users and also causes wastage of time, especially to go to airport etc. places on priority. All such problems can be solved with our code system. Our system through TH code works very accurately and pin point the location, even with poor GPS navigation as our code fixes the location without ambiguity. However, internet connectivity is required.

\subsection{Change of Address}

Many commercial establishments are losing their business due to change of their location. Address shortage is an issue in medical health, especially for old patients [9]. Old customers cannot easily identify the new location of the firm, hospital or establishment. Through complicated address system with extra information provided through land marks etc. is cumbersome to find the new location by the customers. Our code helps in a big way with more accurately without ambiguity. Business addresses are made easy with our code. This way it helps a lot in various business establishments.

Our code provides short business cards, Lengthy business cards will become obsolete. It helps even if the business address changes. For example, Business A 


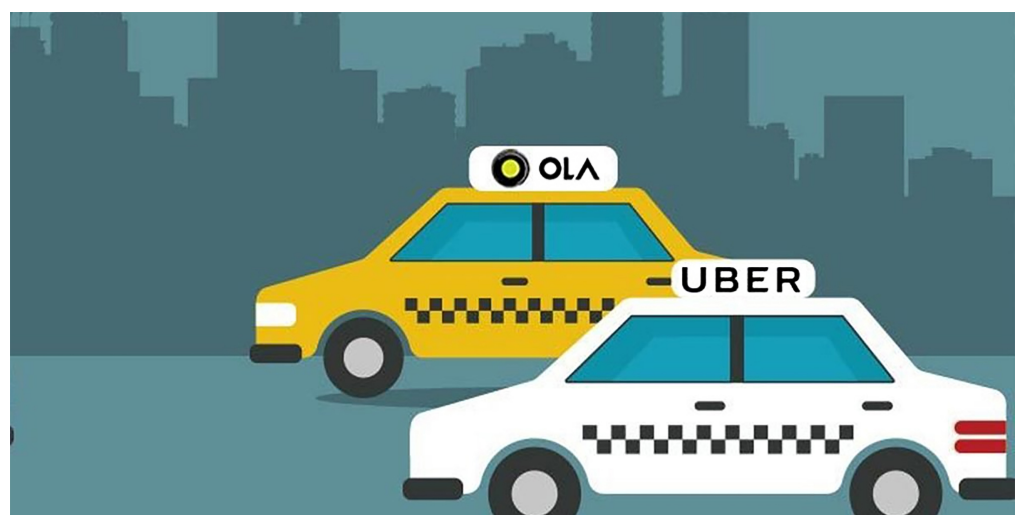

Figure 7. Example of transportation sector: Taxi services such as UBER and OLA can use $\mathrm{TH}$ code more comfortably and reach the location without ambiguity. It helps both the customers and service providers.

has moved from place $\mathrm{X}$ to place $\mathrm{Y}$. A simple board at place $\mathrm{X}$ can say we have moved to ABCD'1234 (Figure 8). This is enough for the users to find a new location easily. The new address may not have house number, street number etc. Still one can find the location without a problem using TH code.

\subsection{E-Commerce}

Nowadays, e-commerce has become multi-billion dollar business and it is doing profitable business in all the countries, especially in China [10]. Among various vendors, Amazon and Flipkart are more popular (Figure 9) in India. Other small vendors like "Big Basket" etc. are also active in India. Similar facilities exist around the world with different vendors. These vendors need a clear address without ambiguity. Unfortunately, all municipalities have not provided clear address system for all the locations. Accordingly, they are not digital and not traceable through internet.

This way the e-commerce vendors cannot accept the commercial orders without proper registered addresses and both the customers and vendors are facing the location problem. Even known address locations are facing severe problem of door delivery, especially at several unpopular locations. By not accepting the orders of the customers, vendors are losing their business. Our code will solve all such problems with ease as explained earlier.

\subsection{Home Service}

Nowadays, "Home Care Services" are coming in a big way [11]. In many countries, older age people are increasing compared to young people. Just like OLA and UBER service, professional service persons are coming into the market and this is great job opportunity for old as well as youngsters. The services include, plumbers, Electricians, Mobile/Internet problem solvers, Home appliance repairers etc. (Figure 10). These professional service providers can share their location dynamically to all. Just like Uber or OLA taxis they can be traced by us. This way, these professional service providers can get more work and can 


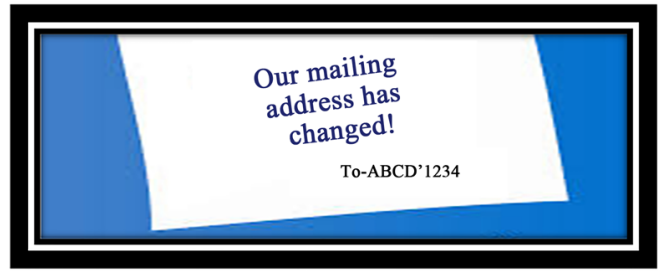

Figure 8. Our new facility in Google APP is quite useful to the merchants who have changed their address. The customers can reach the new location using TH code. This way merchants can continue to have old customers without losing them.

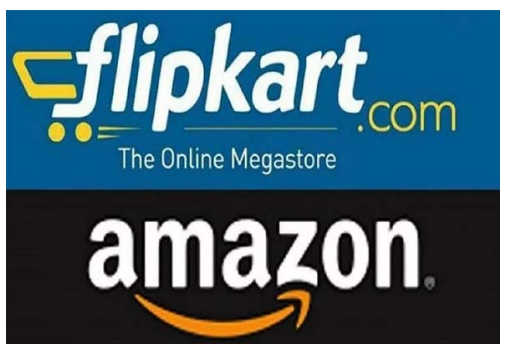

Figure 9. Delivery of goods through various merchants is getting more popular in recent years. Using our TH code, they can deliver the goods without difficulty as it is easy to trace the addresses.

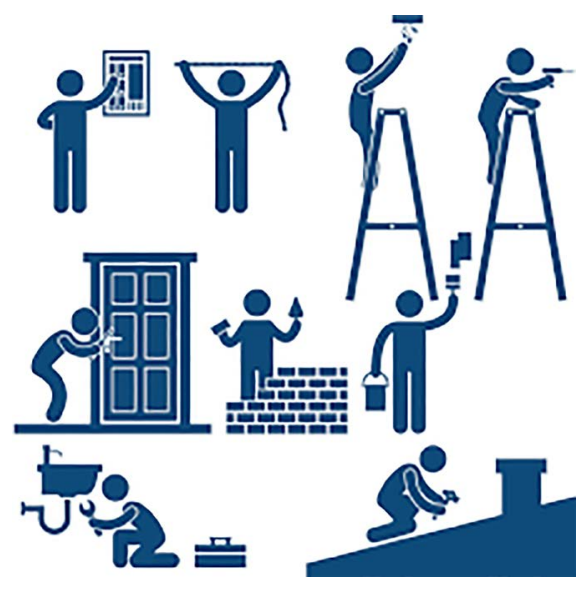

Figure 10. Home-services concept is also getting popular. This generates large employment to the younger generation. They can move freely in the cities and anybody at any time can call them similar to Taxi services of UBER etc. It is very easy for them to reach the needy house locations using our code.

perform quick service without any loss of time. Instead of sending Google location, customers can inform TH code to the vendors in order to find the customers location without difficulty and call them to do the job work at home.

\subsection{Memory in Storage Devices}

In modern days of new technological innovation, one of the new challenges is the development of data-storage devices [12]. Now a days, Data base creation has become mandatory for all institutes, organizations etc. of their employees (Figure 11). Each employee information contains address with a minimum of 


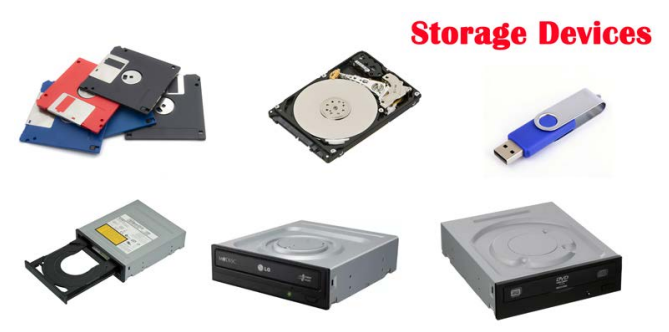

Figure 11. Majority of the organizations, institutes, it is mandatory to store the employee's information in a data base. With just 8 letters one can satisfy the address requirement of the employees. If the organization is dealing with large number of employees, storage of the information is an issue and with our code storage space and also communication of such information with other will become easier occupying less storage space.

four to five lines. If there are millions of employees, huge amount of information to be stored in a computer and thus space for the storage is an issue. Each address of the person occupies about 50 bytes assuming 50 alphabets and our Code requires only 8 bytes. This way the memory storage for the address of the various persons reduces by more than 5 times. This saves lot of space in our computer. Similarly, communication of the address from one system to the other system about the employees can be faster.

\subsection{Navigation at Sea and by Air}

Navigation at Sea and Air (Figure 12(a) and Figure 12(b)) are important to know the ship/aircraft location and its different methods are well described earlier [13] [14]. Instead of communicating with Latitude and Longitude, our code is much simpler to record and communicate. As we all know there are no land marks in open sea or during flight path and one can see water or air in all directions. With our code, one can easily communicate the location of the ship/boat aircraft/helicopter etc. Our TH code works even in small islands where there is no good habitation or proper address system. It works effectively along with GPS system with high accuracy.

In air navigation system, every second, LKC (Last Known Coordinates) will be transmitted from the plane to two or more monitoring stations on the ground. In so doing, some 16- or 20-digit number will be sent to the ground. For quick communication, instead of lengthy numbers, this 8-digit code is enough to find the location of the flight in horizontal plane. This way, computer memory and in turn energy can be saved in the long run and saves time. Additionally, the flight path coordinates storage can be made simple. Instead of a map or long numbers one can store the 8-digit code.

\section{Coronavirus Navigation}

It is well known that the whole world is shivering due to menace created by the virus (Covid-19). Millions of dollars are being spent by many countries to save the lives of their citizens. The trauma being faced by the whole world by all the 


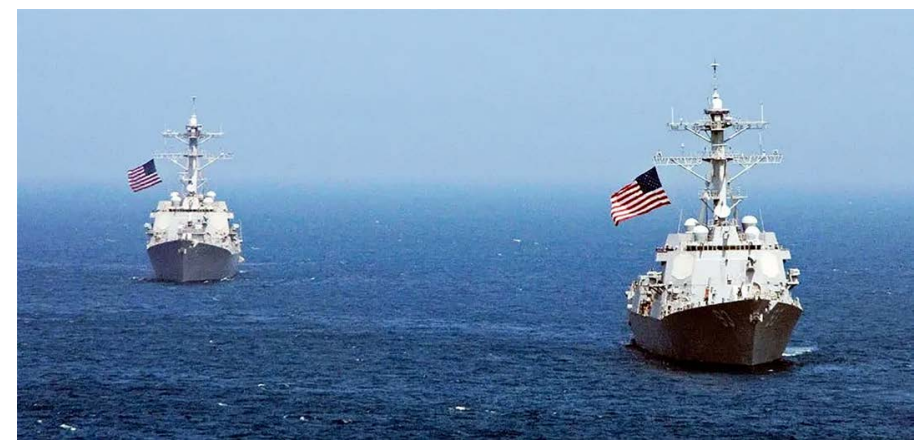

(a)

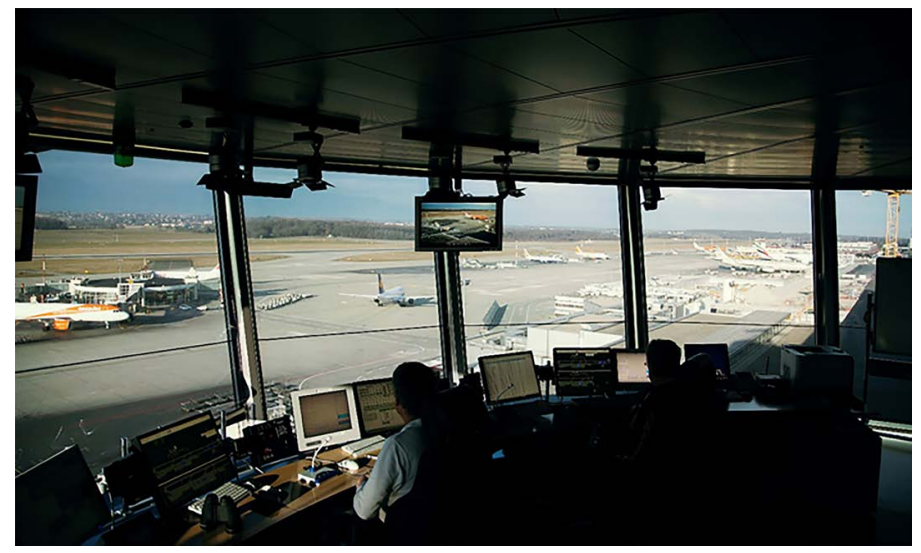

(b)

Figure 12. Navigation in sea or by air involves generation of their location and transmission is an issue. Especially the aircraft location needs to be informed almost continuously to two adjacent navigation centers. It is easier to send 8-digit code rather than large number of digital location numbers both in (a) sea as well as (b) by air.

countries are unimaginable and unique situation in the Human history. W.H.O. has declared this as an epidemic. Everybody knows its origin. But they have no clue to monitor or the procedure to take precautions since its origin and this has resulted in wide spreading. In fact, there was a warning on the spread of the disease as early as March, 2019 [15]. Although their results have been published in a reputed journal, nobody has paid attention to it. Now everybody realized the mistake and it is too late. Some of the country's economy may go upside down and their existence in the coming months to satisfy their citizen's need is a herculean task for them.

One simple way of controlling is to limit the human being's movement from the country of the origin of the disease. Additionally, monitor and restrict the movement of the persons, goods etc. coming from the country of its origin to one's own country. Many countries have neglected this simple solution and not taken enough precautions like India did. The result is well known. As on today (30 $0^{\text {th }}$ April, 2010) the number of deaths has crossed 228,846 ( $>2.28$ Lakhs) and the number of affected persons due to the virus has crossed 3 Million ( $>30$ Lakhs personnel). The worst affected persons are from Europe and US, in addition to the suspected country of origin of the virus disease-China. 
Our App, which is presently working in Android mobile phone can easily be implemented in smart watches as well. This way, every suspected person can be effectively monitored, if provided with irremovable smart watch like "Corona-watch" attached to his hand. This way, movement of the persons who have come from the country of the origin of the disease can be monitored effectively by a centralized station and thus the loss of the human life can be reduced effectively. In severe cases, they can be either self-quarantined or quarantined under police/medical attention etc. to avoid the spread of the disease.

The idea is very simple and similar to sharing the "Google Live location". But our code requires far less memory and consumes far less energy. The button cell battery for the watch can last several months without recharge. The live location for monitoring purpose, could be to send a message through SMS automatically to the central station with TH code for every 15 minutes, 10 minutes or even 5 minutes as per the need. For example, if we want to monitor the person's movement for every 15 minutes it requires to send the message 96 times in a day. The system can be kept in sleeping mode without consuming any energy during off-time. If we can arrange to send the message for every 5 minutes, then the message code needs to be sent 480 times in a day. This way energy consumption for GPS navigation usage and internet usage is very minimal. Eight-digit text message communication consumes far less memory as compared to the passage of information presently being practiced by the Google map. Presently the work is on the way to make this code more popular in all the fields for the benefit of the society.

\section{Comparison}

Our code is superior as compared to the presently available and practicing system to locate a place through Google map. Google has recently introduced "PLUS Code" system as additional feature in their Google Maps APP. For example, with our universal code for our institute (BSAR Crescent Institute of Science and Technology) quarters is $\mathrm{AVw}$ 'Jt0hM corresponding to 12.87587 North and 80.08620 East coordinates. For the same location Google plus code is CHENNAI V3GP + 9G. Thus, this is not universal code and this is regional code. This means one need to mention the area name along with plus code like V3GP $+9 G$, Chennai, to reach the quarters. Otherwise it shows some location in Papua New Guinea or some other place. Similarly, we have tested the use of our TH Code in various locations and addresses to find the destinations around the world as explained earlier and showed more clearly in Tables 1-5 with examples. Accordingly, we claim that our TH Code is unique, more convenient and accurate and can reach precisely to the location. The superior performance can also help courier service using our TH Code as compared to the postal address system using Google maps as described earlier in Section 3.1.

\section{Conclusion}

We have demonstrated the use of our innovation in many areas such as, mobile 
phone, data storage, e-commerce, transportation, emergency services, address in cities, towns and villages etc. and also in monitoring of Corona virus. However, some criticism has come that our TH code is difficult to remember or communicate with others. Another innovation is being finalized such that this $\mathrm{TH}$ code can be further simplified in a simple way such that it is user friendly. The new innovation is involved in reducing the 8 digits to 4 simple unique words. For example, a place can be defined as paper, pen, pencil and eraser. This way one can easily memorize these four simple words. The language presently working on words is ENGLISH language. However, in fact, it can be done in any language with ease such that it will be localized even in village. All villagers can use four simple words who have no knowledge in English language or TH code. For example, in Tamil, Ondru (One), Irandu (Two), Moondru (Three), Naangu (Four) can be defined as a unique place. Similarly, in Telugu, Okati (one), Rendu (two), Moodu (three), Nalugu (four) could be the unique place in the world. Similarly, this concept can be extended to other countries as well. For example, in France, 4 French words, in China, 4 Chinese words, in Japan, 4 Japanese words etc. Our 8-digit universal code can also be reduced further to 6-digit code if we prefer regional or local reference or country specific. More work needs to be done in this direction. However, it is better to practice one universal code using our TH code throughout the world to maintain uniformity.

\section{Acknowledgements}

The present work/ innovation has been filed in the form of a patent at Chennai, India patent office dated 14-10-2019. Our institute welcomes to develop this concept further through collaboration via our website http://www.getme-thcode.com/. Licensing for academic or commercial firms on the use of the existing APP can be negotiated as there are number of areas from which the firms can increase their profit by attracting more customers. We duly thank Dr. Raja Mohammad, Dean, Research group for stimulating discussions. We sincerely acknowledge the help rendered by Dr. Parvez Alam, CEO-CIIC to file this invention as a patent.

\section{Conflicts of Interest}

The authors declare no conflicts of interest regarding the publication of this paper.

\section{References}

[1] Lincoln, D., Vasconcelos, R., Alves, L., André, R. and Endler, M. (2013) A DDS-Based Middleware for Scalable Tracking, Communication and Collaboration of Mobile Nodes. Journal of Internet Services and Applications, 4, Article No. 16. http://www.jisajournal.com/content/4/1/16 https://doi.org/10.1186/1869-0238-4-16

[2] Harrison, R., Flood, D. and Duce, D. (2013) Usability of Mobile Applications Literature Review and Rationale for a New Usability Model. Journal of Interaction Science, 1, Article No. 1. http://www.journalofinteractionscience.com/content/1/1/1 
https://doi.org/10.1186/2194-0827-1-1

[3] Scherrer, L., Tomko, M., Ranacher, P. and Weibel, R. (2018) Travelers or Locals Identifying Meaningful Sub-Populations from Human Movement Data in the Absence of Ground Truth. EPJ Data Science, 7, Article No. 19. https://doi.org/10.1140/epjds/s13688-018-0147-7

[4] Chiang, Y.-Y., Leyk, S. and Knoblock, C.A. (2014) A Survey of Digital Map Processing Techniques. ACM Computing Surveys, 47, 1:1-1:44. https://doi.org/10.1145/2557423

[5] Blondel, V.D., Decuyper, A. and Krings, G. (2015) A Survey of Results on Mobile Phone Datasets Analysis. EPJ Data Science, 4, Article No. 10. https://doi.org/10.1140/epjds/s13688-015-0046-0

[6] Oohama, K.-I. and Asai, Y. (2011) Does Privatization of a Postal Savings Bank in Japan Have Economic Value. iBusiness, 3, 244-247. https://doi.org/10.4236/ib.2011.33032

[7] Bukhari, H., Albazli, K., Almaslmani, S., Attiah, A., Bukhary, E., Najjar, F., et al. (2014) Analysis of Waiting Time in Emergency Department of Al-Noor Specialist Hospital, Makkah, Saudi Arabia. Open Journal of Emergency Medicine, 2, 67-73. https://doi.org/10.4236/ojem.2014.24012

[8] Li, M.X. (2020) Uber Future Value Prediction Using Discounted Cash Flow Model. American Journal of Industrial and Business Management, 10, 30-44.

https://www.scirp.org/journal/ajibm https://doi.org/10.4236/ajibm.2020.101003

[9] Lam, K.L., Tung, H.Y., Ko, K.T., Tsang, K.F., Tung, H.C., Leung, Y.W. and Lau, W.H. (2012) A Study of Address Shortage in a Tree Based ZigBee Network for Mobile Health Applications. Wireless Sensor Network, 4, 147-153. https://doi.org/10.4236/wsn.2012.45021

[10] Han, H.M. (2019) Review and Prospect on Return Problems of E-Commerce Platform. Open Journal of Business and Management, 7, 837-847.

http://www.scirp.org/journal/ojbm https://doi.org/10.4236/ojbm.2019.72057

[11] He, J.H. (2019) Construction of a Diversified Integrated Platform Based on Home Care Services. Open Journal of Social Sciences, 7, 161-167.

http://www.scirp.org/journal/jss https://doi.org/10.4236/jss.2019.76013

[12] Congiu, M., Boratto, M.H., Pica, P. and Graeff, C.F.O. (2018) Development of a Measurement Software for the Characterization of WORM Devices for Novel Memory Storage Applications. Journal of Computer and Communications, 6, 1-13. http://www.scirp.org/journal/jcc https://doi.org/10.4236/jcc.2018.69001

[13] Józef, U., Morgaś, W. and Felski, A. (2008) Maritime Navigation of Today and Tomorrow. Transport Problems: An International Scientific Journal, 3, 51-57.

[14] Barata, J., Mendes, A., Morgado, C., Neves, F. and Silva, A. (2016) The Advent of Scientific Aircraft Navigation. Open Journal of Applied Sciences, 6, 714-727. https://doi.org/10.4236/ojapps.2016.610065

[15] Fan, Y., Zhao, K., Shi, Z.-L. and Zhou, P. (2019) Bat Coronaviruses in China. Viruses, 11, 210. https://doi.org/10.3390/v11030210 